$\xi=\mathbf{\alpha}$

\title{
Entomophagy in traditional healthcare practiced by indigenous communities: potential, implications and constraints
}

\author{
Ruparao T. Gahukar* \\ Arag Biotech Pvt. Ltd., Plot 220, Reshimbag, Nagpur 440009, Maharashtra, India \\ *Corresponding author E-mail: rtgahukar@gmail.com
}

\begin{abstract}
Several insect species including termites, honey bees, American cockroach, grasshoppers, stink bugs, aquatic bugs, silkworms and mopane caterpillars are popularly consumed by indigenous and tribal communities in South America, sub-Saharan Africa, South-east Asia and the Pacific. Different life stages of the insects were found effective in therapeutic treatment against health disorders and life-threatening diseases. In entomophagy (process of insect eating), allergy, content of anti-nutrients, contamination of micro-organisms, chemicals and biochemical compounds, and parasitic infection are major constraints for wide adoption of entomophagy. An urgent attention of policymakers, people's organizations and researchers is therefore needed. This review is focused on worldwide utilization of selected edible insects for therapeutic treatment wherever modern medical facilities are not readily available or indigenous people prefer traditional healers. Certain practical safety measures against anticipated health risk are also elaborated.
\end{abstract}

Keywords: Constraints; Edible Insects; Indigenous Communities; Human Safety; Traditional Healthcare.

\section{Introduction}

Nutritious food is essential to maintain healthy life. Apart from plant-based and animal products, over two thousand edible insects have been reported as food [1]. They are valued as nutritious food to support family livelihood and traditional medicine for nearly two billion people in about 100 countries of the world particularly indigenous communities in the Sub-Saharan Africa, South America, South-East Asia and the Pacific [2]. In these regions, the insect availability and consumers' preference vary considerably [3]. Having easy access to insect collection from the nature/wild round the year, edible insects are consumed for traditional cure/treatment of human diseases/ailments including certain physiological disorders [4]. This is a valid contribution of entomophagy (process of insect eating) to human welfare as nearly $70 \%$ of the populations in economically poor countries rely on traditional medicine for meeting their basic health care needs [5]. This information is available in the country reports and national or regional journals which are not easily accessible to research and extension workers. This review is the first attempt to collate scattered information on traditional medicine, to assess impact of scientific basis and to discuss how the local therapies using edible insects can improve human health in the developing and less developed countries.

\section{Potential of entomophagy in traditional healthcare}

In ancient times, humans ate insects to keep themselves healthy because edible insects were a natural source of protein, unsaturated fat and bioactive substances (carbohydrates, minerals and vitamins).
This means entomophagy is associated with cultural values, religious beliefs and traditional knowledge which could facilitate the understanding and improvement of prevailing health system. [4], [6], [7]. This is relevant to remote areas and forest surrounding areas where the tribal communities visit local traditional healers instead of medical practitioner because of cheaper service, easy access and strong belief in social custom of entomophagy. For example, people in Meghalaya state in India prefer insect-based treatment compared to those of mammalian origin [8]. Of course, the ethnic composition in each country is complex comprising of several ethnic groups that may have specific preference for edible insects. Examples of insects consumed as traditional medicine/treatment are given in Table 1.

It is certain that 30 insect species have been and are being used in traditional/therapeutic treatment or clinical tests against human diseases or disorders. Widely used insects include honey bees, grasshoppers, mulberry silkworm, American cockroach, mopane caterpillar and other lepidopteran larvae and termites. Important effects of edible insects are antibacterial, anti-allergic, antipain and proved helpful against muscular pain, diarrhea, fever, piles and other common disorders. Cure from pneumonia, bronchitis, cold, snake bite etc. has also been reported. To validate entomophagy for public health, inspection of insects for contamination, side effects of over consumption, recognition from the authorized civil and medical authorities need to be addressed appropriately. 
Table 1. Examples of entomophagy as traditional therapeutic measure against certain diseases and health disorders.

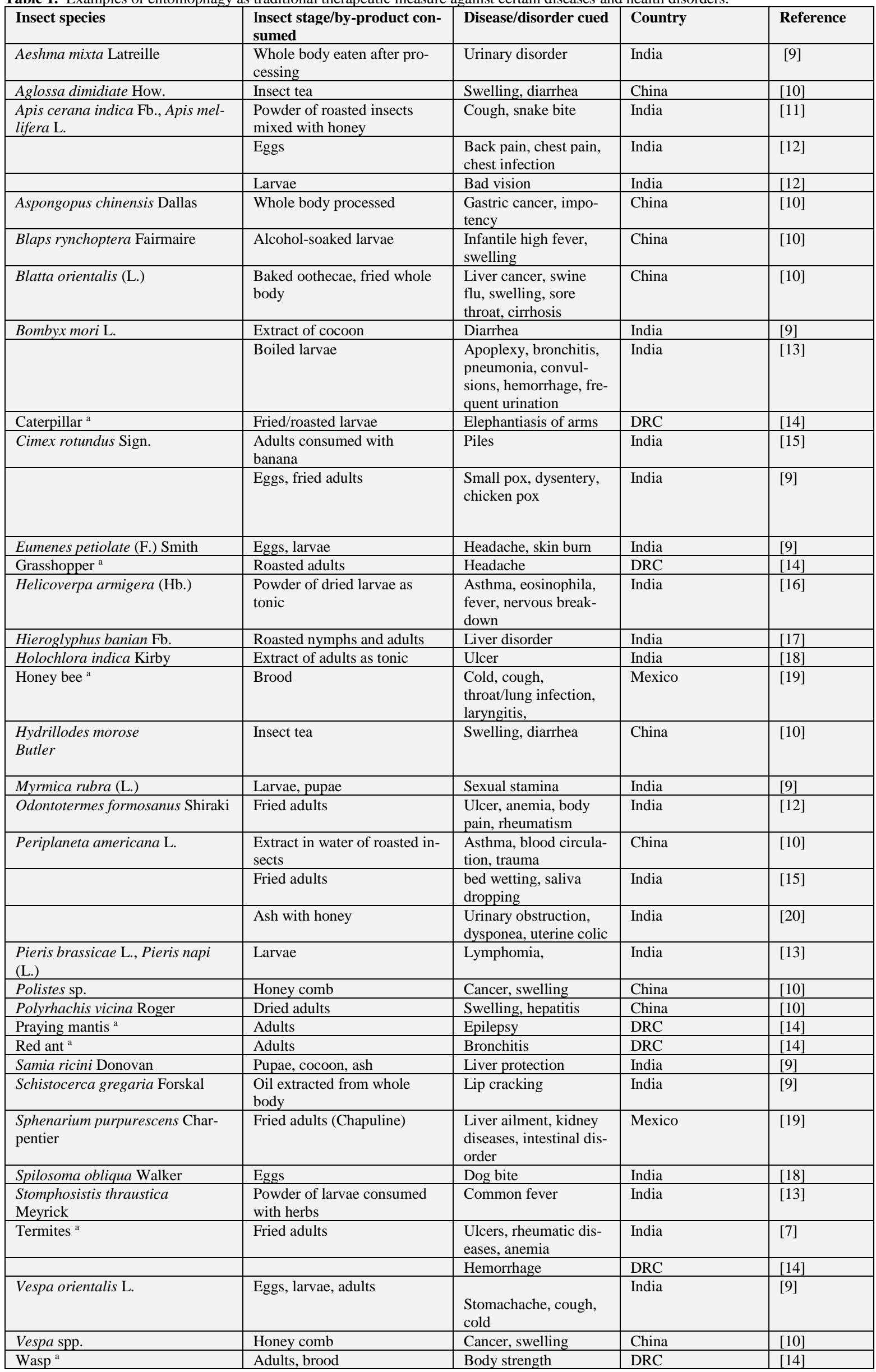

DRC = Democratic Republic of the Congo (Formerly Zaire).

${ }^{a}$ Insect species not specified. 


\section{Impact of entomophagy on human health}

Chitin and chitosans are employed as immune-adjuvants and nonallergic drug carriers [21]. Moreover, they have lipid binding function in human gastro-intestinal track and thus reduce intestinal lipid absorption [22]. They lower plasma cholesterol and triglycerides and improve the HDL/total cholesterol ratio [23]. Silk fiber mats of the weaver ant, spiders and mulberry silkworm are good drug loaders [24]. Oil extracted from adults of termite, Macrotermes bellicosus (Smeathman), mopane caterpillar, Gonimbrasia belina Westwood, coconut rhinoceros beetle, Oryctes rhinoceros (L.) grub and African palm weevil, Rhynchophorus phoenicis (Fb.) grub contain low level of cholesterol and fatty acids but high level of unsaturated fatty acids. Silkworm pupae rich in selenium play an important role in cancer prevention since amino acid content and intracellular reactive oxygen in human hepatoma cells act as carcinostatic agent by inducing apoptosis [25]. Dead larvae and pupae of mulberry silkworm, Bombyx mori (L.) containing high amount of carbohydrates and low fat can be used as nutrition medium for development of fungus, Cordyceps militaris (L.) to produce anti-cancer cordycepin (0.25-2.0 um) that can inhibit the migration of A549 cells [26]. Also, pupae appear to be the potential functional food to protect against alzheimer's disease [27]. Another fungus, Beauveria bassiana (Bals-Criv.) Vuill. growing on silkworm larvae could be used in South Korea to treat heart stroke [28]. Nuclear polyhedrosis virus (NPV) infecting mulberry silkworms was employed by KaonoOkuda et al. [29] as an expression factor of the cDNA encoding human growth hormone.

Chen et al. [30] reported suitability of mulberry silkworm pupae for the expression of heterologous protein as a bioreactor (human granulocyte-macrophage colony-stimulating factor) because pupae could be inoculated with recombinant baculovirus for the expression of protein. The enzyme serrapeptase isolated from bacterium Serratia sp. located in the intestine of silkworm is an immunologically active enzyme. It digests only non-living tissues allowing the old toxic layers to dissolve. It helps to keep arterial deposits from building up after heart surgery [31]. More clinical information on these studies that support these findings would be useful.

Crude extract of the mulberry silkworm was effectively used in cardiac and nervous disorders as it has a significant effect on hypercholesterolemia and atherosclerosis probably because of its anti-oxidant and hypolipidemic effects [32]. Methanol extract $(1 \mathrm{mg} / \mathrm{ml})$ of muga silkworm, Antheraea assamensis Helfer pupae with high content of phenolic acid (11.2 mg catechin/g) and flavonoid (5.12 mg quercetin/g) exhibits anti-oxidant and anti-genotoxic effects and provides protection to $\mathrm{H}_{2} \mathrm{O}_{2}$ induced DNA damage [33]. The major functional component of mulberry silkworm extract powder is alpha-glucosidase inhibitor which exerts blood sugar-lowering effect and is a potential hyperglycemia inhibitor in diabetes patients [34]. Consumption of oil extracted from pupae of eri silkworm, Samia ricini (Donovan) reduces serum cholesterol and triglycerides and increases high-density lipoprotein in cholesterol [35]. Obviously, these findings need further investigations to know how effective they are and how they can be integrated in human diet Evidences on these applications through clinical tests can confirm benefits so that these remedies may be recommended for improving public health.

The bioactive compounds showed potential as therapeutic agents to provide health benefits either as preventive or curative measure. For example, fatty acids in mealworm, Tenebrio molitor L. showed therapeutic effect against alzheimer's disease [36], sterols and sericin from silkworm caterpillars as cure for high blood cholesterol and cardiovascular diseases [37]. Other important impacts include antibacterial effect of a firebug, Pyrrhocoris apterus (L.) [38], antifungal effect of termites [39], skin fibroblast stimulating effect of T. molitor larva and desert locust, Schistocerca gregaria Forsk adult [40]. A few insect species contain flavonoids which act as anti-oxidant, e.g. stink bug, Encosternum delegorguei Spinola adult [41]. Japanese rhinoceros beetle, Allomyrina dichotoma (L.) grub [42], A. assamensis pupa [33] and B. mori pupa [43]. Linolenic acid in edible insects has anticarcinogenic and inflammatory effects [35].

\section{Major constraints of entomophagy}

\subsection{Barrier for ingestion}

It is possible that stones, plastic pieces, metal fragments are mixed or attached to insects and obstruct ingestion. Eating grasshoppers and locusts without removing legs can lead to intestinal blockage with fatal consequences [44]. Palatability of insects is adversely affected by the presence of body hairs [45] because larvae with hairs discharge toxic non-exocrine secretion from poison glands present in hair. Their consumption results in cryptotoxicity and hemorrhage syndrome in humans due to production of powerful fibrinolytic proteinases and can cause histopathological reactions that may be life threatening. In natural process, even though it is possible that proteinaceous constituents of hairs are detoxified in the intestine, major oral injuries can occur before ingestion. As a preventive measure, hairs should be removed by scalding, rinsing or frying before eating.

\subsection{Allergy}

Allergy means adverse health effects arising from a specific immune response that occurs after exposure to edible insects. It is often manifested by mild or serious reactions including dermatitis (pruritus, swelling, erythema, pain) and in some cases, by necrosis [44]. It is therefore necessary to distinguish between allergy and toxic effects. Downs et al. [46] listed several insect allergens that may cause allergy in humans. Allergy has been commonly reported in persons consuming mopane caterpillars in Africa [47, 48], silkworm pupae in China [49, 50, 51], and grasshoppers and locusts in India $[7,13]$. Consumption of $B$. mori pupae (boiled, fried or powdered) causes anaphylactic shock [49].

Pan-allergens and other allergens associated with edible insects can trigger allergic reactions because of cross-infection. In supersensitive persons, the allergic responses can be reduced if edible insects are not eaten with nuts [52], shell fish or molluscs [53].

\subsection{Microbial contamination}

Edible insects containing microbial contaminants (bacteria, fungi, viruses) are potential vectors of food-borne pathogens. Association of bacteria with Oryctes monoceros Olivier grubs [54], R. phoenicis grubs [55,] T. molitor grubs [50), and G. belina larvae [56] and association of fungi with $G$. belina larvae [56] was established. There is also a possibility of transmission of environmentally acquired human viruses (hepatitis or norovirus) from human feces or animal manure when insects contaminated with these materials are consumed [57]. In case of mycotoxins produced by Aspergillus spp. and Penicillium spp., insects collected in the wild were often found infected with these fungi and aflatoxin was detected in mopane caterpillars sold in local markets [58].

Consumption of infected insects should invariably be avoided because their infection can enter the food chain at any step of production, home consumption or marketing. Along with the Good laboratory practices (GLP), preventive measures are needed during collection, transportation, handling and storage of edible insects. Processed insects instead of fresh insects should preferably be consumed. 


\subsection{Parasitic infection}

There is strong possibility that parasites (intestinal flukes, protozoa, nematodes) are carried with insects and transmitted to humans [56]. For example, cockroaches harbor protozoa [59] and ants pass a nematode, Dicrocoelium dendriticum Radolphi to humans [60]

\subsection{Contamination with chemical and biochemical com- pounds}

Naturally occurring compounds may be synthesized and later accumulated in the insect body. Some substances leached during processing may get entry in insect body. Whenever chemicals are used to protect host plants of edible insects, chemical residue is carried into insect body [61]. Eating of poisonous beetles and caterpillars [62] or ground cricket, Brachytrupes orientalis (Fb.) [63] resulted in lead poisoning. Lead, cadmium, chromium and other metals can be transferred to humans through consumption of silkworms fed on mulberry leaves collected from soil polluted fields [64], [65]. Toxic metals can also come from soil treated with synthetic fertilizers and municipal solid waste compost [64]. The stink bugs, E. deregorguei stored in wooden dung-smeared baskets were found contaminated with carcinogenic aflatoxin in Zimbabwe [41]. These chemicals can be localized in specific structures or diffused in different body organs of edible insets and may be detoxified in the food chain [65]. However, overall safety precautions should be taken while consuming insects to avoid unwarranted health complications.

Other toxic substances include metabolic steroids (cause of growth retardation, edema, jaundice, liver cancer), cyanogenetic compounds (cause of inhibition of enzymes) such as, succinate dehydrogenase and carbonic anhydrase, and certain metabolic pathways such as, oxidative phosphorylation), nervous depressants (toxic for brain, kidney and liver), cantharidin (cause of bladder and urethral irritation) [44] and benzoquinones (cause of cytotoxicity [66]. Edema, jaundice and hepatic carcinoma are consequences of prolonged ingestion of anabolic steroids produced by edible insects [44]. Unsaturated aldehydes and 4-methyl-3-heptanone produced by hemipteran insects are odoriferous and distasteful. Therefore, they are generally rejected by the consumers at the oral level [44] Also, possibility of urinary stone formation and development of chronic degenerative disease with excessive consumption of insects collected in forest cannot be overlooked [67].

\subsection{Content of antinutrients}

Table 2. Health hazards of consumption reported for ten insects

\begin{tabular}{|c|c|c|c|c|c|}
\hline Country & Common name & Insect species & Life stage & Hazard & Reference \\
\hline Australia & Bogong moth & Agrotis infusa Boisd. & Adult & Arsenic & [73] \\
\hline Botswana & Mopane worm & $\begin{array}{l}\text { Gonimbrasia belina } \\
\text { Westwood }\end{array}$ & Larva & Fungi, mycotoxins & [76] \\
\hline \multirow[t]{2}{*}{ China } & $\begin{array}{l}\text { Mulberry } \\
\text { Silkworm }\end{array}$ & Bombyx mori L. & Larva & Allergens & [77] \\
\hline & Wild silkworm & $\begin{array}{l}\text { Bombyx mandarina } \\
\text { (Moore) }\end{array}$ & Larva & Allergens & [77] \\
\hline Kuwait & Locust & Locusta sp. & Nymph, adult & Synthetic pesticides & [78] \\
\hline \multirow[t]{3}{*}{ Nigeria } & $\begin{array}{l}\text { African palm } \\
\text { weevil }\end{array}$ & $\begin{array}{l}\text { Rhyncophorus } \\
\text { phoenicis } \mathrm{Fb} \text {. }\end{array}$ & Larva & Metals, minerals & [71] \\
\hline & Emperor moth & Bunaea alcinoe (Stoll) & Larva & Bacteria, fungi & [80] \\
\hline & $\begin{array}{l}\text { African } \\
\text { rhinoceros beetle }\end{array}$ & $\begin{array}{l}\text { Oryctes rhinoceros (Oliv- } \\
\text { ier) }\end{array}$ & Larva & Bacteria & [79] \\
\hline \multirow[t]{2}{*}{ USA } & $\begin{array}{l}\text { Yellow } \\
\text { mealworm }\end{array}$ & Tenebrio molitor (L.) & Larva & Allergens & [81] \\
\hline & Super worm & Zophobas morio $\mathrm{Fb}$. & Larva & Allergens & [81] \\
\hline
\end{tabular}

After the studies of Blum [44], Belluco et al. [82] and van der Spieger et al. [83] on safety of edible insects, following guidelines can be considered for improvement in the current safety norms and further investigations.
Antinutrients are phytochemicals that come from host plants the insects feed upon. Musundire et al. [41] reported content of saponins, alkaloids and tannins to the extent of $53.3 \mathrm{mg} / \mathrm{g}, 52.3 \mathrm{mg} / \mathrm{g}$ and $0.168 \mathrm{mg} / \mathrm{g}$, respectively, in the extract of an orthopteran, Henicus whellani (Watson) from Zimbabwe. Larvae of B. mori collected in Nigeria contained tannic acid (1.93\%), saponins $(6.88 \%)$, alkaloids $(8.55 \%)$, flavonoids $(11.33 \%)$, oxalate $(0.91 \mathrm{mg} / \mathrm{g})$, phylate $(72.89$ $\mathrm{mg} / \mathrm{g}$ ) and phytin phosphorus (20.54 $\mathrm{mg} / \mathrm{g})$ [68]. In O. rhinoceros larvae collected in Nigeria, contents of phytic acid, tannins and oxalates were in the order of $178 \mathrm{mg}, 14.3 \mathrm{mg}$ and $2.1 \mathrm{mg} / 100 \mathrm{~g}$, respectively [69]. Among antinutrients, $\mathrm{HCN}(2.187-3.203 \mathrm{mg} / \mathrm{kg})$, oxalate $(13.20-28.40 \mathrm{mg} / \mathrm{kg})$, phylate $(0.28 \mathrm{mg} / \mathrm{kg})$, tannin $(0.329$ $0.430 \mathrm{mg} / \mathrm{kg}$ ) were analyzed in four insects collected in Nigeria, e.g. cricket, Gryllus lucens Wlk., yam beetle, Heteroligus meles (Billb.), palm weevil, R. phoenicis and variegated grasshopper, Zonocerus variegatus (L.) [70]. High amount of phenol (268 $\mathrm{mg} / 100 \mathrm{~g})$, tannin $(2316 \mathrm{mg} / 100 \mathrm{~g})$, oxalate $(474 \mathrm{mg} / 100 \mathrm{~g})$ and phytin $109 \mathrm{mg}$ in a short-horned grasshopper, Oxya hyla hyla Serville has been reported by Ghosh et al. [71]. These contents were considered below toxic levels and therefore harmless to human health [70], [71].

Antinutrients act in different ways in human body. For example, phylate in phytic acid decreases the bioavailability of mineral elements. It binds $\mathrm{Ca}, \mathrm{Zn}, \mathrm{Mn}, \mathrm{Mg}$ and $\mathrm{Fe}$ to form complexes that are not digestible [69]. Tannins form insoluble complexes with protein thereby interfere with their availability. Tannins are astringent due to their ability to bind with proteins of saliva and mucous membranes. Oxalates can bind calcium present in food and hinder its availability [69].

Health hazards reported in indigenous populations during or after consuming 10 insect species in seven countries are listed in Table 2. These people do not report incidents of toxic effects whether unnoticed or neglected. In some cases, hazardous reactions are not easily recognized because their biochemical products are identical to agents utilized by humans, though in relatively low concentration. Thus, consumption of edible insects is considered safe [72]. However, some insects are toxic and eating them results in acute or chronic toxicity affecting human health, viz. moths of Zygoena sp. and Syntomis sp. [72]. caterpillars of G. belina [73] and adults of Mylabris phalerata Pallas [74]. In any case, safety to humans should be monitored during collection, processing, packaging and transportation of edible insects by regular inspection for any microbial contamination, toxicants and other unwarranted factors

further investigations. 
as vectors or intermediate hosts for vertebrate pathogens could be consumed and might be transmitted to humans.

2) 2. Effects of de-gutted intestine of insect on the population of intestine microflora need further studies.

3) 3. Effects of processing on the microbiological quality are mostly unknown.

4) Toxicological study (dose of toxins that insects excrete at insect development stages at which they are consumed) and pertinent clinical evaluation should be undertaken before insects are served.

5) Possible chemical contamination through residue left in the insects (e.g. dioxins, heavy metals, pesticides, antibiotics, anti-nutrients) is better supervised by regular monitoring before and after shelf life.

6) Risks of all edible insect species and their life stages are not known.

7) Specific regulatory framework for mass production of insects and insect-based products should be documented.

8) Processing of insects to eliminate toxic substances or process contaminants should be improved and included in food chains.

9) Currently, labelling for local insect products is lacking in developing and less developed countries. If introduced, it will boost not only export potential but also ensure food safety to locals.

\section{Future research and extension needs}

1) Regulatory measures governing safety of unprocessed and processed edible insects in rural and tribal areas need attention of policy makers. This aspect is currently relevant to insect collection in the wild which is most vulnerable and prone to human risk due to chemical, allergenic, microbial and other contaminations during collection, handling and serving of "ready to serve" dishes. Specific legislation for insect protein is lacking for effective control of health hazards in conventional production and processing units in localities where GLP can be introduced/developed for controlled systems suitable for developing and less developed countries where food labelling and consumers protection is not followed. A manual of code of recommended practices including safety evaluation methodology and standards for preventing side effects of entomophagy would certainly reduce health hazards.

2) In case of aquatic insects, degradation of water quality due to pollution posing a serious threat. For example, insects in the Loktak lake in Manipur state (India) are vanishing rapidly with increasing environmental pollution [85]. Apart from lake, insects are available in abundance in nearby paddy fields. Locals collect insects and sell them daily in local markets. In recent years, extensive use of synthetic fertilizers and pesticides in paddy cultivation resulted in significant reduction in natural habitat of insects and ultimately, local tribes are losing their traditional food culture [85]. If the concerned farmers are trained for using less toxic or environment friendly pesticides (biopesticides, plant products, pheromones), the survival and augmentation of existing insects would be possible.

3) Several aspects of transforming insect biomass into consumer goods and delicious food recipes have been discussed in detail by Sun-Waterhouse et al. [42]. Processing of edible insects into conventional consumer products has potential for socio-economic development of rural communities [86], [87]. Therefore, insect-based foods can be promoted through local family marketing network.

Overall, the best way for human safety is to avoid collecting insects in the wild. Instead, insect farming in closed environment can provide insects without any disease infection and chemical residues $[61,87]$. Another way is the processing such as, frying, boiling, roasting, drying, smoking or grilling that greatly reduces content of anti-nutrients and increases protein solubility depending upon $\mathrm{pH}$ of insect body part [88].

\section{Conclusions}

With increasing awareness of entomophagy for healthy life, more research is needed to understand consequent implications of entomophagy on human health particularly in areas where the undernourishment or malnutrition is common. The content of micronutrients, vitamins and protein in edible insects is generally equal to or higher than what $\mathrm{FAO} / \mathrm{WHO}$ recommended for human consumption. These contents can support therapeutic treatments practiced in tribal and other indigenous communities. Entomophagy can be of immense help whenever getting service of medical practitioner is not possible or people prefer traditional healer due to cultural and religious beliefs.

Facilities of infrastructure (analysis of residue of contaminants, training to local entrepreneurs, facilities for storing processed insects etc.) should be created in tribal villages. These steps would assure conventional insect eaters residing in the forests and neighboring areas the safe and nutritious insects in the period of famine or penury and for daily food. Allergy and microbial and chemical contamination are major constraints to entomophagy. However, awareness of consumption of healthy insects (collected or farmed) can promote entomophagy in remote areas where other food sources (grains, meat) are not accessible or costly.

\section{Acknowledgement}

I express my sincere thanks to Dr M. Kashettiwar, MBBS, MD, Nagpur, India, for his valuable suggestions on the text related to human physiology.

\section{Conflict of interest}

The author declares no potential conflict of interests.

\section{References}

[1] Mitsuhashi J. 2017. Edible Insects of the World. CRC, Boca Raton, FL, USA.

[2] Hanboonsong Y, Jamjanya T, Durst DB. 2013. Six-legged Livestock Edible Insect Farming, Collection and Marketing in Thailand. FAO Regional Office for Asia and the Pacific, Bangkok, Thailand (Publication no. 2013/03).

[3] Gahukar RT. 2011. Entomophagy and human food security. International Journal of Tropical Insect Science, 31: 129-144. https://doi.org/10.1017/S1742758411000257.

[4] Feng Y, Zhao,M, He Z, Chen Z, Sun L. 2009. Research and utilization of medicinal insects in China. Entomological Research, 39: 313 316. https://doi.org/10.1111/j.1748-5967.2009.00236.x.

[5] WHO (World Health Organization). 2002. Traditional Medicine Strategies 2002-2005. WHO, Geneva, Switzerland.

[6] Chen X, Feng Y, Chen Z. 2009. Common edible insects and their utilization in China. Entomological Research, 39: 299-303. https://doi.org/10.1111/j.1748-5967.2009.00237.x.

[7] Chakravorty J, Ghosh S, Meyer-Rochow VB. 2011. Practices of entomophagy and entomotherapy by members of the Nyishi and Galo tribes, two ethnic groups of the state of Arunachal Pradesh (North East India). Journal of Ethnobiology and Ethnomedicine, 7(1): 1-5

[8] Sharma VP, Khan AU. 1995. Drugs of mammals' origin used by aborigines of Garo hills of Meghalaya state, India. Anand, 15(1): 1-55

[9] Ronghang R, Ahmed R. 2010. Edible insects and their conservation strategy in Karbi Anglong district of Assam, North-East India. Bioscan (Special Issue), 2: 515-521

[10] Yi C, He Q, Wang L, Kuang R. 2010. The utilization of insect-resources in Chinese rural area. Journal of Agricultural Science, 2(3): 146-154. https://doi.org/10.5539/jas.v2n3p146.

[11] Solanki GS, Chutia P. 2008. Entomophagy in tribal communities in Arunachal Pradesh. National Journal of Life Sciences, 5: 281-284. 
[12] Wilasanand V, Preema V, Rajitha P. 2007. Therapeutic of insects and insect products in south Indian traditional medicine. Indian Journal of Traditional Knowledge, 6: 563-568.

[13] Srivastava SK, Babu N, Pandey H. 2009. Traditional insect bioprospecting as human food and medicine. Indian Journal of Traditional Knowledge, 8: 485-494.

[14] Latham P. 2001. Edible Caterpillars of the Bas Congo Region of the Democratic Republic of Congo. Forneth, London, UK, 41 pp.

[15] Ayekpam N, Singh NI, Singh T. 2014. Edible and medicinal insects of Manipur. Indian Journal of Entomology, 76(3): 256-259.

[16] Oudhia P. 2001. Traditional medicinal knowledge about pod borer, Helicoverpa armigera in Chhatisgarh, India. International Chickpea \& Pigeon pea Newsletter, 1: 14-15.

[17] Alemla AM, Singh HK. 2004. Utilization of insects as human food in Nagaland. Indian Journal of Entomology, 8: 308-310.

[18] Gope B, Prasad B. 1983. Preliminary observations on the nutritional value of some edible insects of Manipur. Journal of Advanced Zoology, 4: 55-61.

[19] Ramos-Elorduy J, Pino-Moreno JM. 1988. The utilization of insects with empirical medicine of ancient Mexicans. Journal of Ethnobiology, 8(2): 195-202.

[20] Padmanabhan P, Sujana RA. 2008. Animal products in traditiona medicine from Attappady hills of western ghats. Indian Journal of Traditional Knowledge, 7(2): 326-329.

[21] Muzzarelli RAA. 2010. Chitins and chitosans as immunoadjuvants and non-allergic drug carriers. Marine Drugs, 8: 292- 312. https://doi.org/10.3390/md8020292.

[22] Koide SS. 1998. Chitin-chitosan: properties, benefits and risks. Nutrition Research, 18(6):1091-1101. https://doi.org/10.1016/S02715317(98)00091-8.

[23] Williams JP, Williams JR, Kirabo A, Chester D, Peterson M. 2016. Nutrient content and health benefits of insects, In Dossey AT, Morales-Ramos JA, Rojas MG (eds) Insects as Sustainable Food Ingredients: Production, Processing and Food Applications, Elsevier Inc. New York, USA, pp. 61-84. https://doi.org/10.1016/B978-0-12802856-8.00003-X.

[24] Reddy N, Yu H, Yang Y. 2011. Unique natural protein hollow-nanofibre membranes produced by weaver ants for medical applications. Biotechnology and Bioenergy, 108:1726-1733. https://doi.org/10.1002/bit.23076.

[25] Hu D, Liu Q, Cui H, Wang H, Han D, Xu H. 2005. Effects of amino acids from selenium rich silkworm pupas on human hepatoma cells. Life Sciences, 77(17): 2098-2110. https://doi.org/10.1016/j.lfs.2005.02.017.

[26] Aramwit P, Bang N, Ratanavaraporn J, Nakpheng T, Srichana T. 2014. An anti-cancer cordycepin produced by Cordyceps militaris growing on the dead larva of Bombyx mori silkworm. Journal of Agricultural Science, 6(6): 41-53. https://doi.org/10.5539/jas.v6n6p41.

[27] Wattanathorn J, Muchimapura S, Boosel A, Kongpw S, Kaewrueng W, Tong-Un, T, Wannanon P, Thukhammee W. 2012. Silkworm pupae protect against alzheimer's disease. American Journal of Agricultural and Biological Sciences, 7: 303-336. https://doi.org/10.3844/ajabssp.2012.330.336.

[28] Pemberton RW. 1999. Insects and other arthropods used as drugs in Korean traditional medicine. Journal of Ethnopharmacology, 65: 209-216. https://doi.org/10.1016/S0378-8741(98)00209-8.

[29] Kaono-Okuda K, Yamamoto M, Higashino Y, Taniai K, Kato Y Chowdhury S, Xu J, Choi SK, Sugiyama M, Nakashima K, Maeda S, Yamakawa M. 1995. Baculovirus-mediated production of the human growth hormone in larvae of the silkworm, Bombyx mori. Biochemical and Biophysical Research Communications, 213(2): 389 390. https://doi.org/10.1006/bbrc.1995.2144

[30] Chen J, Wu XF, Zhang YZ. 2006. Expression, purification and characterization of human GM-CSF using silkworm pupae (Bombyx mori) as a bioreactor. Journal of Biotechnology, 123(2): 236-247. https://doi.org/10.1016/j.jbiotec.2005.11.015.

[31] Escr PM, Gerngross H, Fabian A. 1989. Objective measurement of swelling of the upper ankle joint in treatment with serrapeptase: a prospective study. Fortsch Med 107(4): 67-68, 71-72 (in German with English abstract)

[32] Ali MM, Bharati AAS. 2011. Effect of crude extract of Bombyx mori cocoons in hyperlipidemia and artherosclerosis. Journal of Ayurveda and Integrative Medicine, 2(2):72-78. https://doi.org/10.4103/09759476.82527.

[33] Deori M, Boruah DC, Devi D, Devi R. 2014. Antioxidant and antigenotoxic effects of pupae of the muga silk worm, Antheraea as samensis. Food Bioscience, 5: 108-114. https://doi.org/10.1016/j.fbio.2013.12.001.
[34] Heo HS, Choi JH, Kang BH. 2013. Evaluation of general toxicity and genotoxicity of the silkworm extract powder. Toxicology Research, 29: 263-278. https://doi.org/10.5487/TR.2013.29.4.263.

[35] Longvah T, Mangthya K, Ramalu P. 2011. Nutrient composition and protein quality evaluation of eri silkworm (Samia ricini) prepupae and pupae. Food Chemistry, 128: 400-403. https://doi.org/10.1016/j.foodchem.2011.03.041.

[36] Youn K, Yun EY, Lee J, Kim JY, Hwang JS, Jeong WS, Jun M. 2014. Oleic acid and linoleic acid from Tenebrio molitor larvae inhibit BACE1 activity in vitro, molecular docking studies. Journal of $\begin{array}{llll}\text { Medicinal } & \text { Food, } & \text { 284-289. }\end{array}$ https://doi.org/10.1089/jmf.2013.2968.

[37] Cheseto X, Kuate SP, Tchouassi DP, Ndung'u M, Teal PEA, Torto B. 2015. Potential of the desert locust, Schistocerca gregaria (Orthoptera: Acrididae) as an unconventional source of dietary and therapeutic sterols. PloS ONE, 10(5): e0127171. https://doi.org/10.1371/journal.pone.0127171.

[38] Cociancich S, Dupont A, Hegy G, Lanot R, Holder F, Hetru C, Bulet P. 1994. Novel inducible antibacterial peptide from hemipteran insect, the sap-sucking bug, Pyrrhocoris aptarus, Biochemistry Journal, 300 (Part 2): 567-575.

[39] Lamberty M, Zachary DR, Bordereau C, Robert A, Hoffman JM, Bulet P. 2001. Insect immunity, constitutive expression of a cysteinerich antifungal and a linear bacterial peptide in a termite insect. Journal of Biological Chemistry, 276(6): 4085-4092. https://doi.org/10.1074/jbc.M002998200.

[40] Zielinska E, Baraniak B, Karas M, Rybczynska K, Jakubczyk A. 2015. Selected species of edible insects as a source of nutrient composition. Food Research International, 77: 460-466 https://doi.org/10.1016/j.foodres.2015.09.008

[41] Musundire R, Osuga IM, Cheseto M, Irungu J, Torto b. 2016. Aflatoxin contamination detected in nutrient and anti-oxidant rich edible stink bug stored in recycled grain containers. PLoS ONE, 11(1) e0145914. Doi: https://doi.org/10.1371/journal pone.0145914.

[42] Sun-Waterhouse D, Waterhouse GIN, You L, Zhang J, Liu J, Liu Y, Ma L, Gao J, Dong Y. 2016. Transforming insect biomass into consumer wellness foods: a review. Food Research International, 89: 129-151. https://doi.org/10.1016/j.foodres.2016.10.001.

[43] Yang R, Zhao V, Kuang Z, Ye M, Luo G, Xiao G, Xiong Z. 2013. Optimization of antioxidant peptide production in the hydrolysis of silkworm (Bombyx mori L.) pupa protein using response surface methodology. Journal of Food, Agriculture \& Environment, 11(1) 952-956.

[44] Blum M. 1994. The limits of entomophagy: a discretionary gourmand in a world of toxic insects. Food Insects Newsletter, (1): 1, 6 11.

[45] Berenbaum M .1993. Sequestered plant toxins and insect palatability. Food Insects Newsletter, 6(3): 1, 6-9.

[46] Downs S, Johnson P, Zeece P. 2016. Insects and their connection to food allergy, In: Dossey AT, Morales-Ramos JA, Rojas MG. (eds) Insects as Sustainable Food Ingredients: Production, Processing and Food Applications, Elsevier Inc. New York, USA, pp. 255-309. https://doi.org/10.1016/B978-0-12-802856-8.00009-0.

[47] Okezie OA, Kgomotso KK, Letswiki MM. 2010. Mopane worm allergy in a 36-year old woman: a case report. Journal of Medical Case Reports, 4: 42. https://doi.org/10.1186/1752-1947-4-42.

[48] Kung SJ, Fenemore B, Potter PC. 2011. Anaphylaxis to mopane worms (Imbrasia belina). Annals of Allergy, Asthma \& Immunology, 106: 538-540. https://doi.org/10.1016/j.anai.2011.02.003.

[49] Ji KM, Zhan ZK, Chen JJ, Lieu ZG. 2008. Anaphylactic shock caused by silkworm pupa consumption in China. Allergy, 63: 14071408. https://doi.org/10.1111/j.1398-9995.2008.01838.x

[50] Liu XD, Tian JJ, Chen DM. 2001. An allergic shock case that resulted from consuming silkworm pupae. Chinese Recuperative Medicine, 10: 80

[51] Liu Z, Xia L, Wu Y, Xia Q, Chen T, Roux KH. 2009. Identification and characterization of an arginine kinase as major allergen from silkworm (Bombyx mori) larvae. International Archives of Allergy and Immunology, 150: 8-14. https://doi.org/10.1159/000210375.

[52] MacEvilly C. 2000. Bugs in the system. Nutrition Bulletin, 25: 267 268. https://doi.org/10.1046/j.1467-3010.2000.00068.x.

[53] Barre A, Caze-Subra S, Gironde C, Bienvenu F, Bienvenu J, Rouge P. 2014. Entomophagie et risqué allergique. Revue Francaise d' Allergie, 54(4): 315-321. https://doi.org/10.1016/j.reval.2014.02.181.

[54] Banjo A.D, Lawal OA, Adeyemi AI .2006. The microbial fauna associated with the larvae of Oryctes monoceros gut and body surface samples showed presence of Staphylococcus aureus, Pseudomonas aeruginosa, Bacillus firmus. Journal of Applied Sciences Research, 2(11): 837-843. 
[55] Opara MN, Sanyigha FT, Ogbuewu IP, Okoli IC. 2012. Studies on the production trend and quality characteristics of palm grubs in the tropical rainforest zone of Nigeria. International Journal of Agricultural Technology, 8(3): 851-860.

[56] Marshall DL, Dickson JS, Nguyen NH. 2016. Ensuring food safety in insect food: Mitigating microbiological and other food borne hazards, In: Dossey AT, Morales-Ramos JA, Rojas MG. (eds) Insects as Sustainable Food Ingredients: Production, Processing and Food Applications, Elsevier Inc. New York, USA, pp. 223-254. https://doi.org/10.1016/B978-0-12-802856-8.00008-9.

[57] Wei J, Jin Y, Sims T, Kniel K. 2010. Survival of murine norovirus and hepatitis A virus in different manure and biosolids. Foodborne Pathogens and Disease, 7: 901-906. https://doi.org/10.1089/fpd.2009.0490.

[58] Schaber HG. 2010. Forests insects as food: a global review. In: Durst DB, Johnson DB, Leslie RN, Shono K (eds), Forest Insects as Food: Humans Bite Back, Proceedings of a workshop on Asia-Pacific resources and their potential for development. 11-19 February 2008, FAO, Chiang-Mai, Thailand, FAO Regional Office for Asia and the Pacific, Bangkok, Thailand (Publication no. 2010/02), pp. 637-642.

[59] Graczyk TK, Knight R, Tamang I. 2005. Mechanical transmission of human protozoan parasites by insects. Clinical and Microbiological Review, 18: 128-132. https://doi.org/10.1128/CMR.18.1.128132.2005.

[60] Jeandron A, Rinaldi I, Abdyldaleva G, Usubalieva J, Steinmann.P, Cringoli, G, Utzinger J. 2011. Human infections with Dicrocoelium dendriticum in Kyrgyzstan: the tip of the iceberg? International journal of Parasitology, 97: 1170-1172. https://doi.org/10.1645/GE2828.1.

[61] Gahukar RT. 2014. Impact of major biotic factors on tropical silkworm rearing in India and monitoring of unfavourable elements: a review. Sericologia, 54: 150-170.

[62] Phillips J, Burkholder W. 1995. Allergies related to food insect production and consumption. Food Insects Newsletter, 8(2): 1-2, 4.

[63] Chakravorty J, Ghosh S, Meyer-Rochow VB. 2014. Nutritional composition of Chondacris rosea and Brachytrupes orientalis: two common insects used as food by tribes of Arunachal Pradesh (India). Journal of Asia-Pacific Entomology, 17(3): 407-415. https://doi.org/10.1016/j.aspen.2014.03.007.

[64] Zhao S, Shang X, Duo L. 2013. Accumulation and spatial distribution of $\mathrm{Cd}, \mathrm{Cr}$ and $\mathrm{Pb}$ in mulberry from municipal solid waste compost following application of EDTA and (NH4)2SO4. Environmental Science Pollution Research International. 20: 967-975. https://doi.org/10.1007/s11356-012-0992-Z.

[65] Zhou.Z, Zhao Y, Wang S, Han S, Liu J. 2015. Lead in the soil - mulberry (Morus alba L.) - silkworm (Bombyx mori) food chain: translocation and detoxification. Chemosphere 128:171-177. https://doi.org/10.1016/j.chemosphere.2015.01.031.

[66] Crespo R, Villaverde ML, Girotti JR, Guercif A, Juarez MP, de Bravo MG. 2011. Cytotoxic and genotoxic effects of defence secretion of Ulomoides dermestoides on A549 cells. Journal of Ethnopharmacy, 136(1): 204-209. https://doi.org/10.1016/j.jep.2011.04.056.

[67] Yhoung-Aree J. 2010. Edible insects in Thailand: nutritional values and health concerns. In: Durst DB, Johnson DB, Leslie RN, Shono K (eds) Forest Insects as Food: Humans Bite Back, Proceedings of a workshop on Asia-Pacific resources and their potential for development. 11-19 February 2008, FAO, Chiang-Mai, Thailand, FAO Regional Office for Asia and the Pacific, Bangkok, Thailand (Publication no. 2010/02), pp.201-216,

[68] Omotoso OT. 2015. An evaluation of the nutrients and some antinutrients in silkworm, Bombyx mori L. (Bombycidae: Lepidoptera). Jordon Journal of Biological Sciences, 8(1): 45-50. https://doi.org/10.12816/0026947.

[69] Ifie I, Emeruwa CH. 2011. Nutritional and antinutritional characteristics of the larva of Oryctes rhinoceros. Agriculture and Biology Journal of North America, 2(1): 42-46. https://doi.org/10.5251/abjna.2011.2.1.42.46.

[70] Ekpo KE. 2010. Nutrient composition, functional properties and anti-nutrient content of Rhynchophorus phoenicis (F.) larva. Annals of Biological Research, 1(1): 178-190.

[71] Ghosh S, Haldar P, Mandal DK. 2016. Evaluation of nutrient quality of a short-horned grasshopper, Oxya hyla hyla Serville (Orthoptera: Acrididae), in search of new protein source. Journal of Entomology and Zoology Studies 4(1), 193-197.

[72] Zagrobelny M, Dreon AL, Gomiero T, Marcazzan GL, Glaring MA, Moller BL, Paoletti MG. 2009. Toxic moths: source of a truly safe delicacy. Journal of Ethnobiology, 29: 64-76. https://doi.org/10.2993/0278-0771-29.1.64.
[73] Lee JA, Hathaway SC. 1998. The challenge of designing valid HACCP plans for new food commodities. Food Control, 9: 111-117. https://doi.org/10.1016/S0956-7135(97)00061-3.

[74] Hanboonsong Y. 2010. Edible ad associated food habits in Thailand, In: Durst DB, Johnson DB, Leslie RN, Shono K (eds) Forest Insects as Food: Humans bite back, Proceedings of a workshop on Asia-Pacific resources and their potential for development. 11-19 February 2008, FAO, Chiang-Mai, Thailand, FAO Regional Office for Asia and the Pacific, Bangkok, Thailand (Publication no. 2010/02), pp.173-182.

[75] Green K, Broome L, Heinze D, Johnstone S. 2001. Long distance transport of arsenic by migrating Bogong moths from agricultural lowlands to mountain ecosystems. Victorian Naturalist, 118(4): 112 116.

[76] Simpanya MF, Allotey J, Mpuchan, SF. 2000. A mycological investigation of phane: an edible caterpillar of an emperor moth, Imbrasia belina. Journal of Food Protection, 63: 137-140. https://doi.org/10.4315/0362-028X-63.1.137.

[77] Lian Y, Liu Z. 2006. Advances in silkworm pupa allergy and their allergens. Journal of Tropical Medicine, 6: 224-226.

[78] Saeed T, Dagga FA, Saraf M. 1993. Analysis of residual pesticides present in edible insects captured in Kuwait. Arab Gulf Journal of Scientific Research, 11(1): 1-5.

[79] Banjo AD, Lawal OA, Fasunwon BT, Alimi GO. 2010. Alkali and heavy metal contamination of some selected edible arthropods in south western Nigeria. American-Eurasian Journal of Toxicological Sciences, 2(1): 25-29.

[80] Braide W, Oranusi S, Udegbunam LI, Oguoma O, Akobondu C, Nwaoguikpe RN. 2011. Microbiological quality of an edible caterpillar of an emperor moth, Bunacea alcinoe. Journal of Ecology and the Natural Environment, 3(5): 176-180.

[81] Freye HB. 1996. Anaphylaxis to the ingestion and inhalation of Tenebrio molitor (mealworm) and Zophobas mori (superworm). Allergy, Asthma Proceedings, 17(4):215-219. https://doi.org/10.2500/108854196778996903.

[82] Belluco S, Losasso C, Maggioletti M, Alonzi CC, Paoletti MG, Ricci A. 2013. Edible insects in a food safety and nutritional perspective: a critical review. Comprehensive Reviews of Food Science and Food Safety, 12(3): 296-313. https://doi.org/10.1111/1541-4337.12014.

[83] Van der Spieger M, Noordam MY, van der Fels-Klenx HJ. 2013. Safety of novel protein sources (insects, microalgae, seaweed, duckweed and rapeseed) and legislative aspects for their application in food and feed production. Comprehensive Reviews of Food Science and Food Safety, 12(6): 662-678. https://doi.org/10.1111/15414337.12032.

[84] Allotey J, Mpuchane S. 2003. Utilization of useful insects as food source. African Journal of Food, Agriculture, Nutrition and Development, 3(2): 112-121.

[85] Samom S. 2016. Edible aquatic insects vanishing from Lokak. The AssamTribune, May 19, 2016, Imphal, Manipur, ndia.

[86] Doley AK, Kalita J. 2011. An investigation on edible insects, their role in socio-economic development of rural communities: A case study of edible insects in Dhemaji district of Assam (India). Social Science Researcher, 1(1): 11.

[87] Gahukar RT. 2016. Edible insects farming: efficiency and impact on family livelihood, food security and environment compared to livestock and crops. In: Dossey AT, Morales-Ramos JA, Rojas MG (eds) Insects as Sustainable Food Ingredients: Production, Processing and Food Applications, Elsevier Inc. New York, USA, pp. 85111. https://doi.org/10.1016/B978-0-12-802856-8.00004-1.

[88] Womeni HM, Tiencheu B, Linder B, Nabayo EMC, Tenyang N, Mbiupo FT, Villeneuve P, Fanni J, Parmentier M. 2012.Nutritional value and effect of cooking, drying and storage process on some functional properties of Rhynchophorus phoenicis. International Journal of Life Science and Pharma Research, 2(3): 203-219. 